\title{
Dzienniki Adeli Kieniewicz: kobieta pisząca przełomu XIX i XX wieku
}

Katarzyna Nadana-Sokołowska

TEKSTY DRUGIE 2019, NR 1, S. 303-320

DOI: 10.18318/td.2019.1.21 | ORCID: 0000-0003-4207-414X

... bez czytania i pisania czas się tak dłuży... ${ }^{1}$

Pokoik na górze, w nim cenne pamiątki z dzieciństwa, chyba lalki.

Potem hol lub nawet piwnica o chropowatych, białawych ścianach. Jakaś kobieta $\mathrm{z}$ determinacją drapie po nich, nie pamiętam, czy nie wręcz paznokciami, chcąc utrwalić jakieś zdania. Słyszę ostry szelest osypującego się żwiru.

Odjazd. Pilą ją, aby wsiadła do bryczki, ale wyrywa się z powrotem do domu, do tego pokoiku, z którego chciałaby, z którego musi zabrać coś dla niej bezcennego. Nie pozwalają, pokrzykują na nią, czas goni. Jako obserwator tej sceny nie rozumiem, dlaczego, bo wokół nic specjalnego się nie dzieje. Słyszę jeszcze jej rozdzierający krzyk ZABIJASZ MOJĄ DUSZĘ! i budzę się.

1 A. Kieniewicz Dziennik, Centralne Historyczne Archiwum Państwowe Ukrainy w Kijowie, Kolekcja Muzeum Wołyńskiego, f. 2227, op. 1, spr. 967, k. 143 b.
Katarzyna Nadana-Sokołowska - dr, IBL PAN, współwykonawczyni projektów zespołu "Archiwum kobiet". Zajmuje się autobiografistyką, krytyką feministyczną, George Sand i filozofią religii. Ostatnio - współautorka Między sztuką a codziennościq̨. Wstronę nowej syntezy, t. 1-3, red. M. Hopfinger, Z. Ziątek, T. Żukowski (2016-2018). Kontakt: katarzyna.nadana-sokolowska@ibl. waw.pl. 
Obserwując sny od wielu lat, jestem gotowa myśleć, że nie wszystkie są moje. Na przykład ten, który właśnie opisałam. Zdziwił mnie, ale nie czułam, aby mnie dotyczył, więc rano nie sięgnęłam po dziennik, żeby go zapisać. Przypominał raczej scenę z może oglądanego kiedyś filmu.

Zaczęłam się nad nim zastanawiać dopiero wieczorem. Jeśli nie mój, to czyj?

Poprzedniego dnia położyłam się spać tuż po północy, doczytawszy do końca kolejny tom dzienników Adeli Kieniewicz. Ich skany udostępnił zespołowi realizującemu projekt „Archiwum Kobiet: piszące” zespół prof.Wiesława Cabana, który odnalazł je w czasie kwerend w Kijowie ${ }^{2}$. Sczytuję je w pewnych odstępach czasu, między czytaniem innych książek, między pisaniem innych tekstów, od ponad roku. Na swój sposób uzależniona już od tej lektury, raportuję czasem koleżankom z zespołu rozczarowanie: „wcale nie taka ciekawa”, „jakaś dziwna”, „dewotka”, „nic mnie z nią nie łączy”.

Poza płcią, narodowością i potrzebą pisania dzienników. To dlatego, kiedy o nich usłyszałam, natychmiast zgodziłam się je w całości przeczytać.

Wydawałoby się, że Adela Kieniewicz nie mogła trafić na lepszą czytelniczkę. Bardzo lubię czytać dzienniki, od wielu lat zajmuję się nimi zawodowo, a jako "genderystka" wiem dużo o uwarunkowaniach egzystencji kobiet, ich często skrytych nieszczęściach i pragnieniach.

Więc? Dlaczego się nie polubiłyśmy?

Może winne są jej wielkopańskość, wyjątkowe poczucie wartości własnej i - zupełnie mi obcy - typ religijności? Nigdy chyba np. nie zrozumiała, jak nieludzki był jej stosunek do służącej Józefy. Sąsiedztwo dwóch ostatnich tematów nieuchronnie przywoływało na myśl znaną bajkę Krasickiego.

Ale może wybaczyłabym jej i Józefę, gdyby po prostu miała dar bardziej zajmującego mnie spisywania tysięcy zdarzeń, rozmów i myśli własnych? Z czasem przekonałam się, że Adela Kieniewicz najbardziej interesująca jest dla mnie w swoich słabościach - tam, gdzie niebezpieczna bliskość wzniosłości i trywialności albo niekonsekwencja autorki stwarzają w tekście efekty groteskowe, najwyraźniej w swoim czasie dla niej niewidoczne. To na nie

2 Por. Pamiętniki i listy polskich autorów z Ziem Zabranych (Litwa, Białoruś, Ukraina) w latach 1795-1918. Materiały do katalogu, t 1: Pamiętniki rękopiśmienne i drukowane, red. M. Domańska-Nogajczyk, T. Wójcik, W. Caban, L. Michalska-Bracha, Uniwersytet Jana Kochanowskiego, Kielce 2018; oraz R. Kowalczyk, S. Krawczenko Obraz polskiej ziemianki w listach i pamiętnikach z lat 1795-1918 znajdujących się w Centralnym Archiwum Historycznym w Kijowie (Dziennik Adeli Kieniewicz, 1888-1915, t. 1-38), w: Polskie dziewiętnastowieczne pamiętniki i listy z Ziem Zabranych, rola i miejsce w badaniach historycznych, red. W. Caban, L. Michalska-Bracha, DiG, Warszawa 2017. Zachowane tomy dziennika mają w kolekcji sygnatury: f. 2227, op. 1, spr. 948-986. 
reaguję najżywiej, rozbawieniem albo irytacją. Wydają mi się także bardzo znaczące. Ale jak wyciągać podobne zdania z tekstu, nie obrażając jej (nie) pamięci?

Jak wypełnić zadanie, które nieopatrznie na siebie wzięłam?

Chciałam przecież, jak napisałam rok temu we własnych notatkach, oddać jej sprawiedliwość. Odpomnieć w sposób, który mógłby jej sprawić satysfakcję, używając przy tym najlepiej jak potrafię narzędzi, którymi dysponuję, aby dowiedzieć się więcej o sytuacji kobiet w jej czasach i ich praktykach diarystycznych.

Od kilku dni pracuję nad tekstem o jej dziennikach i wiem, że bardzo by zranił jej ogromną miłość własną. Jak to się mówi: „przewróciłaby się w grobie".

Nachodzi mnie nagle bardzo nieprzyjemna myśl: a co, jeśli to jednak do mnie wykrzyczała tamte słowa?!

Mam potrzebę zacząć pisać artykuł jeszcze raz, inaczej.

*⿻一从十

Tom 83. w numeracji autorki ${ }^{3}$ zamyka wpis z 27 maja 1914 roku. Poza rzadkimi wzmiankami o sytuacji swojej grupy społecznej, religijnej i narodowej na Kresach i równie rzadkimi krytycznymi uwagami o socjalistach i emancypantkach, Adela Kieniewicz (1870-1935) nigdy nie pisała o polityce. Teraz także jej (jeszcze?) nie zajmuje. Z poczuciem wyższości zanotowała niedawno, że jej mąż jest katastrofistą, bo nie widzi przyszłości dla Polaków na tych terenach. Właśnie zrezygnował z pełnienia kilku honorowych urzędów, twierdząc, że chce z nią spędzać więcej czasu. Wywołał tym niezadowolenie ambitnej żony, która nie dowierza jego zapewnieniom i nie szczędzi ostrych słów w dzienniku. Z niedawnej wizyty na Wołyniu Hieronim Kieniewicz (1866-1925) przywiózł ponure wieści o fali bankructw wśród tamtejszych administratorów majątków. Od kilku tygodni przez ich rozmowy przewija się temat koniecznych cięć w budżecie domowym. To nie wywołuje jej protestu, bo od dawna aspiruje do miana ascetki.

Czym sama się w tym czasie zajmuje? Czy groza nadchodzącej wojny i rewolucji naprawdę nie kładzie się jeszcze cieniem na jej życiu?

Na pozór skupia się, jak zawsze, na czymś innym. Przede wszystkim na sobie. Na wrażeniu, jakie (z)robi tym czy owym. Na postępach duchowych,

3 A. Kieniewicz Dziennik, spr. 982. 
pragnieniu bliskości z Bogiem i posłuszeństwie Jego woli. Na pomaganiu biednym.

W ciągu ostatnich kilku miesięcy przeżyła wielki osobisty zawód, z którym teraz, w połowie maja, wydaje się pogodzona. Ma już ponad czterdzieści lat i mimo wieloletnich starań nie urodziła dziecka, co znaczy, że najstarsza linia rodu Kieniewiczów wygaśnie z jej powodu (?).W pobliskich Dereszewiczach gospodaruje młodszy brat męża, Antoni Kieniewicz, któremu bratowa urodziła już pięciu synów. Adela Kieniewicz, skądinąd bardzo towarzyska, stroni od tych dzieci. Przez wiele lat pisze o bratowej z wielką niechęcią i we własnej wyobraźni nieustannie z nią rywalizuje.

Kiedy Magdalena Grabowska pojawiła się na horyzoncie, Adela Kieniewicz była pewna swego: większej urody, większych talentów towarzyskich i artystycznych, lepszego gustu, chyba nawet tego, że jest bardziej od niej kochana przez jej przyszłego męża. Ale „Madalon”, później po prostu „Madzia", urodziła pierwsze dziecko jeszcze w roku zamążpójścia, natomiast ona, wtedy od siedmiu lat mężatka, żadnego. W tomie dziennika, który właśnie skończyłam, nazwie bratową „zmorą”, a Dereszewicze „[swoim] czyśćcem na ziemi"s. W dzienniku z 1900 roku brak potomstwa nie wydaje się jej bolączką. Ledwo dwa razy, mimochodem, wspomina o radach, które ktoś przy niej udzielał bezdzietnym małżeństwom. Ale już w następnym tomie, oczekując z niepokojem na małżeństwo brata męża i określając je wielką zmianą w swoim życiu, przeżywa kryzys związany z ciążą urojoną. Dziecko, oczywiście chłopiec -zawsze pisze o nim jako o synu - w następnych zachowanych tomach stanie się obsesją.

Pod koniec 1913 roku ${ }^{6}$, a więc bardzo wcześnie, Adela Kieniewicz traci „regle”. Wyczekuje ich z początku z wielkim niepokojem, niemal odchodząc od zmysłów. Dużo czasu spędza w łóżku, skarżąc się na wyjątkowe boleści, w których na przemian doszukuje się objawów ciąży albo powracającej miesiączki. Co jakiś czas szuka na pościeli i bieliźnie śladów krwi, rozmawia o swoim nieszczęściu ze służącymi i członkami rodziny, przyjmuje gości (w tym Antoniego Kieniewicza) w alkowie, nie całkiem ubrana, i notuje ich reakcje. Czytuje im fragmenty dawnych dzienników, kajając się z powodu opisanej w nich własnej „lubieżności”. O jej zmartwieniu wie cała okolica,

\footnotetext{
4 A. Kieniewicz Dziennik, spr. 982, k. 154 b.

5 A. Kieniewicz Dziennik, spr. 982, k. 131.

6 Por. A. Kieniewicz Dziennik, spr. 981.
} 
a wieśniaczki, chcąc się jej przypodobać, utwierdzają ją w przekonaniu, że to ciąża. Niestety, lekarze nie chcą potwierdzić jej nadziei.

Wkrótce małżonkowie wyjeżdżają na trzy tygodnie do Drezna, gdzie uczęszczają na konsultacje z dr Gösslem, jasnowidzem i magnetyzerem, a zarazem cieszą się piękną okolica, robiąc także wycieczkę do Pragi. Po wyjeździe z Drezna Adela Kieniewicz zapisze, że dr Gössel wyleczył ją z melancholii Nic dziwnego: dał jej nadzieję na odmłodnienie, powrót menstruacji i zajście w ciążę, a także wiele cennych rad dotyczących zachowania zdrowia obojga małżonków. Na początku kwietnia wracają na Polesie, do Bryniowa - majątku sąsiadującego z Dereszewiczami, w którym od zawsze zamieszkują. Temat braku miesiączki i dziecka schodzi nieco na dalszy plan; autorka znów, jak prawie zawsze, gdy jest u siebie na wsi, oddaje się przede wszystkim rozmyślaniom i praktykom pobożnym.

Tylko że w tym tomie opisy jej filantropijnej aktywności ze strony na stronę budzą we mnie coraz większe zdziwienie. Zabiera się do niej z całą swą energią, jest w tym wręcz... rozpasana? Marzy jej się przemiana domu w klasztor i umieszczenie nad bramą napisu „Królestwo ubogich”. Notuje w dzienniku, że „[dąży] do tego ażeby Bryniów się zamienił w Jerozolimę niebieską"' i że „[jej] obecnym zadaniem jest wprowadzenie i szerzenie Królestwa bożego na całej kuli ziemskiej"10.

Nie jestem pewna, czy wszystko dobrze rozumiem. Upewniam się w podejrzeniach, dopiero, kiedy Kieniewiczowa, będąc w maju w Warszawie, spisuje treść rozmów ze swoim wieloletnim spowiednikiem, prałatem Załuskowskim.

Nie pierwszy raz jest w dzienniku zdumiona jego reakcją: „Zabronił mi mycia nóg biednym, prania dla nich, dojenia krów na korzyść sierot, w ogóle to wszystko co może na mnie ściągnać uwagę"11.

Habit, który ostatnio nosiła po domu, pozwolił jej nosić tylko w pierwszy piątek miesiąca, zalecił za to asystowanie mężowi przy śniadaniu. Przynależne jej sferze obowiązki rodzinno-towarzyskie powinny być dla niej najważniejsze, napominał. Kazał także dziękować Bogu za „wyjątkowego męża”,

7 A. Kieniewicz Dziennik, spr. 982, k. 41.

8 A. Kieniewicz Dziennik, 982, k. 134 b.

9 A. Kieniewicz Dziennik, 982, k. 123.

10 A. Kieniewicz Dziennik, 982, k. 156.

11 A. Kieniewicz Dziennik, 982, k. 186. 
który „na wszystkie [jej] wybryki pozwala”12. Pozwolił jej za to pisać Sataniella i „inne utwory świeckie”: „Sama się dziwię swemu szczęściu: A więc będę mogła w dalszym ciągu pracować nad moim «Sataniello»!"13

Od wielu lat stara się uczciwie trzymać zaleceń prałata, ale nie pierwszy raz wydają jej się sprzeczne. Przecież to od jego rekolekcji wielkanocnych w roku 1909 odmawiała sobie tej ogromnej przyjemności. Nieoczekiwana aprobata wywołuje w niej radość.

\section{Prawdziwa mania}

Adela Kieniewiczowa, córka Heleny z Czosnowskich i Antoniego Jodko-Narkiewicza, kolekcjonera i historyka sztuki (1843-1892), do zamążpójścia w roku 1894 mieszkała w Wolicy na Wołyniu. Jej życie upływałoby potem w sposób typowy dla kobiety z kręgu zamożnego ziemiaństwa - dzieleniu życia domowego z mężem, bywaniu na spotkaniach towarzyskich, wyjazdach do miast stołecznych i za granicę - gdyby nie ważne odstępstwo od reguły: bezdzietność, a także chyba jej niezwykły charakter.

Otrzymawszy wykształcenie domowe, znając kilka języków i posiadając pewne zdolności artystyczne, we własnym poczuciu bardzo atrakcyjna, uwielbiająca taniec, Kieniewiczowa czuła się duszą spotkań w jej kręgu rodzinno-towarzyskim. Wielokrotnie wyrażała też w dzienniku chęć rozwijania talentów - tych dobrze widzianych w przypadku kobiet, jak śpiew czy rysunek - i tych postrzeganych wciąż jako pewna ekstrawagancja, jak twórczość literacka.

Dzienniki z lat 1888-1915 obejmują dwadzieścia siedem lat życia autorki. Nie wszystkie tomy trafiły do kolekcji, o czym wiemy dzięki lukom w ich autorskiej numeracji. Prawie dziewięćdziesiąt na pewno istniejących kiedyś tomów zostało spisanych w zeszytach liczących około 200 kart $^{14}$. Obszerność całego dzieła można więc oszacować na około 35000 stron. Zeszyt wystarczał zwykle autorce do prowadzenia zapisków zaledwie przez 3-4 miesiące, przy czym o ile wczesne zachowane dzienniki nie są pisane regularnie, o tyle późne mają wyraźne cechy wspólne: przeważają w nich długie wpisy dzienne. Tym samym możemy określić praktykę diarystyczną

12 A. Kieniewicz Dziennik, 982, k. 189 b.

A. Kieniewicz Dziennik, 982, k. 189 b.

14

Wszystkie zachowane tomy trzymają się jednego formatu, więc przyjmuję, że zaginione także go zachowywały. 
Adeli Kieniewicz jako wyjątkowo intensywną i uznać ją za typową diarystkę zgodnie z rozumieniem Béatrice Didier: osobę, która przez całe życie lub jego znacząco długi okres silnie odczuwa potrzebę prowadzenia dziennika, a zapisywanie w nim kolejnych kart staje się ważnym codziennym rytuałem. Z dużą pewnością, na podstawie zwyczajów diarystów, moglibyśmy przypuścić, że autorka prowadziła dziennik aż do końca życia ${ }^{15}$, choć wstrząs wojny, rewolucji i przymusowa przeprowadzka do Warszawy mogły coś zmienić w jej zwyczajach.

O wadze, jaką Kieniewiczowa przywiązywała do dziennika, świadczą poza wyrażonymi wprost uwagami na ten temat - starannie sporządzone strony tytułowe każdego tomu, na których wypisywała daty rozpoczęcia i zakończenia prowadzonych w nim zapisków oraz miejsce ich sporządzenia; wspomniana odautorska numeracja dzienników; rozbudowany sposób datowania; czytelne, a w pewnych partiach wręcz kaligraficzne pismo, a także sygnały ponownego odczytywania już spisanych tomów: czy to w postaci informacji wewnątrztekstowej, czy informacji płynącej z cech zapisu. Są to dopiski czerwonym atramentem, w odróżnieniu od czarnego, w którym zapisane są partie główne: drobne poprawki, uzupełnienia, podkreślenia, nadawane niektórym stronom tytuły w nagłówku, czasem drobne, schematyczne rysuneczki, powiązane tematycznie z zapiskami. Z treści dziennika wiemy, że autorka nie szczędziła czasu na pisanie, a choć do jego poufności przywiązywała dużą wagę, z jego prowadzenia nie robiła tajemnicy i czasem odczytywała fragmenty wybranym osobom.

$\mathrm{Na}$ tle dotąd poznanych ${ }^{16}$, dzienniki Adeli Kieniewicz stanowią unikatowe w skali polskiej świadectwo tak intensywnej kobiecej praktyki diarystycznej, sięgającej przedostatniego dziesięciolecia XIX wieku i trwającej przez niemal trzy dekady ${ }^{\mathbf{1 7}}$. Najregularniej prowadzone, a zarazem dotąd

Por. A. Pekaniec Czy w tej autobiografii jest kobieta? Kobieca literatura dokumentu osobistego od początku XIX wieku do wybuchu II wojny światowej, Księgarnia Akademicka, Kraków 2013; E. Kolinko Dziennik Heleny Krukowieckiej (1831-1833) w kontekście diarystyki kobiecej w epoce, niepublikowana praca doktorska złożona u prof. E. Wichrowskiej, Wydział Polonistyki Uniwersytetu Warszawskiego.

Dziennik Adeli Kieniewicz najwyraźniej i jej rodzinnemu otoczeniu wydawał się czymś niezwykłym na tle powszechności praktyki diarystycznej kobiet, bo zarówno Janina Żółtowska, jak i Antoni Kieniewicz poświęcają mu po kilka akapitów w swoich wspomnieniach. Nie dowiemy się jednak z nich nic o okolicznościach utraty starego, ani o pisaniu nowego. Co jednak ciekawe, oboje wspominają, że Kieniewiczowa prowadziła równolegle dwa dzienniki, nazywając je "ma- 
najważniejsze z punktu widzenia historii literatury, polskie dzienniki kobiece nieprzypadkowo powstały dopiero w XX wieku: są powiązane z ideami modernizmu, w tym z nowymi koncepcjami kobiecego „ja” i sztuki. O ponad dekadę młodsza od Adeli Kieniewicz Zofia Nałkowska zapisuje we wczesnym dzienniku, prowadzonym od 1899 roku, ideowe zmagania o rozumienie własnej kobiecości i - silnie powiązanej z nim - twórczości. Jej dziennik jest świadectwem drogi do pisarstwa pojmowanego z jednej strony jako najpełniejszy wyraz jej niezwykłej indywidualności, z drugiej więzi ze sprawami epoki, ówczesnej kultury i społeczeństwa, wchodzi także w specyficzne związki z jej twórczością powieściową i publicystyczną ${ }^{18}$. Czy poza systematycznością przedsięwzięcia znajdziemy inne cechy wspólne między ich dziennikami?

Adela Kieniewicz także marzyła czasami o karierze literackiej. Jak wynika z dziennika, pisała przede wszystkim krótkie dramaty (głównie jasełka i moralitety) na użytek teatru domowego. Była wśród nich jednak także opowieść dramatyczna pod tytułem Śmierć, która wyraźnie nawiązywała do średniowiecznych przedstawień danse macabre, ale i poetyki Młodej Polski ${ }^{19}$. Śledziła polską literaturę współczesną, ale nie miała o niej wysokiego mniemania ${ }^{20}$.Z entuzjazmem wspominała za to często polskich romantyków oraz d’Annunzio i Hyusmansa. Od około 1900 roku snuła plany napisania obszernego utworu pod znaczącym tytułem Sataniello. Plany te, a właściwie ich porzucanie i ponawianie, stanowią ważny wątek dziennika, powracający na przestrzeni kilkunastu lat.

Jeśli czytać dziennik Kieniewiczowej w kontekście diarystycznego przedsięwzięcia Nałkowskiej, to jako znak pewnej więzi między nimi można potraktować słynny wtedy dziennik Marii Baszkircew, wydany po raz pierwszy (we fragmentach, z cenzurą obyczajową) w roku 1887. Philippe Lejeune w Le moi

łym" $i$ „ dużym". Mały był rodzajem agendy, w której m.in. notowała pośpiesznie rozmaite fakty, by potem opisać je szczegółowo w "dużym". Por. J. Żółtowska Inne czasy, inni ludzie, Alma Book, Londyn 1959 i A. Kieniewicz Nad Prypeciq, dawno temu... Wspomnienia z zamierzchłej przeszłości, Ossolineum, Warszawa-Wrocław-Kraków-Gdańsk-Łódź 1989.

Por. Z. Nałkowska Dzienniki, t. 1-6 (1899-1954), oprac. H. Kirchner, Czytelnik, Warszawa 1975-2001 .

Por. A. Kieniewicz Dziennik, spr. 969, k. 143 b- 144.

20

W dzienniku znajdziemy np. krótkie uwagi o lekturze Żeromskiego, Tetmajera, Zapolskiej czy Przybyszewskiego, zwykle bardzo krytyczne. Interesują ją jednak dzieła wyrażające tęsknotę metafizyczną, np. Na drogach duszy Przybyszewskiego. 
des demoiselles ${ }^{21}$ podkreślał jego niezwykłość na tle sposobów autoreprezentacji kobiet w XIX-wiecznych francuskich dziennikach panieńskich, które związane były z konserwatywną, katolicką ideologią negacji kobiecego „ja”. Wskazywał jednocześnie na istnienie „sióstr Baszkircew”, które mimo tej presji wykazywały w dziennikach z końca XIX wieku wolę autoafirmacji i autoekspresji.

O ile w młodzieńczym dzienniku Nałkowskiej Baszkircew stanowi ważny pozytywny układ odniesienia, o tyle Kieniewiczowa zaświadcza o jego znajomości w zupełnie innym kontekście. W Wielkanoc 1910 roku w Dereszewiczach zagaja dyskusję wokół niego w obecności filozofa Adama Żółtowskiego. Pyta, czy jako badacz twórczości romantycznych wieszczów pochwala dążenie do sławy jako pobudkę twórcząą . Najwyraźniej nawet w przypadku "geniuszy" autorka jest ją gotowa potępić i - zgodnie z sądem właściwym uwewnętrznionej przez siebie pobożności katolickiej - wyrzec się twórczości, o ile jej pobudki są egoistycznej natury.

Jesteśmy tu u źródła konfliktu wewnętrznego, który całymi latami dręczy autorkę.

\section{Światowa i melancholijna}

Jeśli uznamy, że forma, jaką przyjmuje u danego autora praktyka diarystyczna, jest powiązana z jego rozumieniem własnej tożsamości, to dziennik Adeli Kieniewicz można określić jako formę odzwierciedlającą poczucie wartości „ja" oraz (w dużej mierze nieświadomą) potrzebę zachowania go, wbrew świadomie wyrażanej zgodzie na konserwatywną wizję powołania kobiety, a także wbrew własnej, rosnącej wyraźnie z latami, gorliwości w praktykach religijnych, zmierzających do „całkowitego poddania się woli bożej” i „uśmiercenia ja”. Przy czym trzeba zaznaczyć, że wczesne dzienniki autorki różnią się mocno formą od dzienników z przełomu stuleci, a te z kolei różnią się od dzienników pisanych pod koniec pierwszej dekady XX wieku i później. Ewolucja formy wyraźnie odpowiada tu zmianom w sytuacji życiowej, usposobieniu i poglądach autorki²3.

21 Por. Ph. Lejeune Le moi des demoiselles. Enquête sur le journal de jeune fille, Éditions du Seuil, Paris 1993.

$$
\text { kę }
$$
kę domowo-towarzyską, prawie pozbawioną warstwy osobistej i refleksyjnej. Dziennik podróży został napisany w języku francuskim, dziennik z 1891 roku w polskim i francuskim, dzienniki z XX wieku są pisane przede wszystkim po polsku i mają już charakter intymny. 
W dzienniku Kieniewiczowa opisywała życie codzienne, składające się na przemian z okresów wyraźnie nudnego w jej odczuciu bytowania na wsi oraz życia towarzyskiego typowego dla uprzywilejowanej sfery, do której należała. W okresach małej aktywności zewnętrznej relacjonuje sposoby wypełniania obowiązków jako żona, pani domu i opiekunka włościan (dobrowolnie podejmowane obowiązki nauczycielskie, pielęgniarskie, opiekuńcze, kaznodziejskie) oraz oddaje się refleksjom natury filozoficzno-religijnej. Ceni samotność jako czas, który może poświęcić samej sobie i ulubionym zajęciom: lekturze, pisaniu, rozpamiętywaniu, ale i boi się jej, bo na wsi dopadają ją depresja i apatia. W innych okresach dokładnie relacjonuje przebieg rautów, bali, przyjęć, polowań, wizyt w muzeach i teatrze, spacerów po miastach czy zwiedzania zabytków. Spisuje, zwykle po francusku, fragmenty toczących się rozmów. Podobne wydarzenia wydają się ją wtedy całkowicie absorbować, tak jakby towarzyskość była jej właściwym żywiołem: warstwa refleksyjna dziennika prawie tu zanika.

Autorka często pisze o stosunku do męża. Przeważają rozczulenia i wyrazy zadowolenia z małżeństwa; nie ukrywa przy tym, że znaczący element relacji stanowi pożycie seksualne, które uważa za udane i którego pewne szczegóły czasem zdradza. Z drugiej strony nie brakuje opisów scen, które robi mężowi, a w dzienniku z 1900 roku znajdziemy wręcz opis zainicjowanej przez siebie awantury, w której wyraziła nienawiść do niego i Polesia oraz pragnienie powrotu na Wołyń ${ }^{24}$.

Z treści zapisków, w tym autocharakterystyk, wynika, że Adela Kieniewicz była skłonna do przeżywania ekstremalnych stanów emocjonalnych: entuzjazmu, wesołości, wzmożenia życiowej energii i aktywności, silnego gniewu i zazdrości, ale także wstrętu do życia ${ }^{25}$. Podkreślała często dwoistość swojej natury: zarazem światowej i melancholijnej. Przypisywała sobie także skłonność do mistyki i wyrażała czasem tęsknotę za życiem klasztornym. Po śmiałym opisie pieszczot z mężem zapisze kiedyś, że nie starcza jej miłość ziemska: „ja pragnę czegoś większego, nieskończonego, czegoś niepojętego"26. Mimo to przymusowe odosobnienie na poleskiej wsi wydaje się jedną z głównych przyczyn jej życiowej frustracji. Jej temperament, potrzeba samoekspresji i aktywności, niepokój wewnętrzny, silne i ambitne „ja”, wreszcie -

\footnotetext{
24 Por. A. Kieniewicz Dziennik, 957, k. 181 b.

25 Por. np. A. Kieniewicz Dziennik, spr. 982, k. 155.

26 Por. A. Kieniewicz Dziennik, 965, k. 125.
} 
potrzeba nadania sensu własnej egzystencji, sprawią, że nigdy nie wystarczy jej świat zastany, do którego, zgodnie z ówczesnymi normami kobiecości, powinna się dostosować. Czuła to niedopasowanie, nazywając się czasem "molem książkowym” i „podłą żoną" dobrą matką, i dochodziła czasem do wniosku, że brak dziecka jest pewną wartością: dzięki temu ma czas na czytanie i pisanie.

Szczególny wątek dziennika stanowi relacja do Antoniego Kieniewicza i jego żony. Temat napięcia erotycznego między autorką dziennika a młodszym od niej bratem męża pojawia się w różnym natężeniu i odcieniach we wszystkich tomach dziennika z okresu ich znajomości - jakby autorka miała długo potrzebę pragnąć rozkoszy zakazanych, być może dla samej przyjemnej ekscytacji z tym związanej. $Z$ czasem przyjmie ona postać rozpominania, choćby ze skruchą, atmosfery lat młodości. Jego małżeństwo w 1901 roku być może rzeczywiście było ważną cezurą w życiu bratowej, ponieważ w okresie przygotowań do niego w jej dzienniku pojawiają się - na razie rzadko - nowe wątki, które z czasem będą dominować. Są to: przeżywana we własnym umyśle rywalizacja na wszystkich polach z (przyszłą) żoną szwagra dramat związany z brakiem dziecka i starania o nie, które znajdą odzwierciedlenie w opisach coraz to nowych kuracji na bezpłodność; oraz zaangażowanie religijne autorki. Kieniewiczowa wyraźnie boleje też nad faktem, że nie może wpisać się w najbardziej typowy, usankcjonowany obyczajem i religią scenariusz życia kobiety-ziemianki-matki dziedzica, a narodziny kolejnych chłopców w Dereszewiczach wyraźnie źle wpływają na jej nastrój.

Najważniejszą funkcją dziennika Kieniewiczowej wydaje się funkcja mnemotechniczna. Zgodnie z rozpoznaniami Harriet Blodgett ${ }^{28}$ można zatem stwierdzić, że praktyka diarystyczna Kieniewiczowej odbija niewyrażone wprost przekonanie autorki, że jej osoba i życie są warte upamiętnienia. $\mathrm{Na}$ podstawie dziennika wypada uznać, że autorka posiada duże poczucie wartości własnej. Potrafi doceniać samą siebie za wygląd, talenty, stosunek do życia. Często i z przyjemnością odnotowuje komplementy otoczenia - rodziny, znajomych, służby, włościan. Jest próżna, ma potrzebę bycia adorowaną, imponowania innym swoją osobą i osiągnięciami. Dziennik tyleż poczucie wartości odzwierciedla, co dodatkowo intensyfikuje.

27 Por. np. A. Kieniewicz Dziennik, spr. 983, k. 15 b.

28 Por. H. Blodgett Centuries of Female Days. English Women's Private Diaries, Alan Sutton, Gloucester 1989. 
Pisanie dziennika jest tu ważnym - szczególnie na wsi - sposobem spędzania czasu („prawdziwa mania"29), ale i sposobem na uporanie się z rozstrojem nerwowym wywoływanym przez różne wydarzenia ("gdyby przeczyszczającym środkiem dla duszy" ${ }^{\prime 30}$ ). Jest także związane z potrzebą autorefleksji, uporządkowania stosunku do życia. Z czasem pobożność sprawi, że

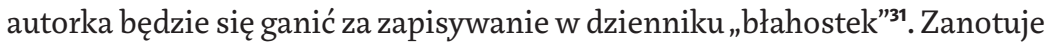
na przykład: „Dziennik mój powinien być odtąd rachunkiem sumienia a nie fotografią głupiego" ${ }^{\prime 32}$. Mimo to charakter zapisków nie zmienia się znacząco, a sama autorka docenia je wielokrotnie za szczerość. Mówi wręcz, że dziennik wyraża jej „nagą duszę" ${ }^{\text {”3 }}$. Nie boi się jego przyszłych czytelników, mimo często wstydliwej zawartości ${ }^{34}$.

Do formy dziennika modernistycznego zbliża dziennik Kieniewicz poza ostatnią cechą zaskakująca bezpruderyjność autorki w opisywaniu fizjologii i seksualności (w tym fantazji erotycznych). Autorka przypisuje sobie „lubieżność" i nie kryje upodobania do flirtu. Z czasem zacznie z tego powodu wyrażać skruchę, chętnie jednak przy okazji przyznając się nawet do epizodów zainteresowania we wczesnej młodości kobietami. Notuje także fizjologiczne szczegóły wciąż nowych kuracji na bezpłodność: praktyk, które z konieczności naruszają granice intymności w relacji z innymi, o czym pisze w dzienniku szczerze, czasem z uchwytną przyjemnością.

Prowadzenie dziennika w wypadku Kieniewiczowej wyraźnie wiąże się także z silnie odczuwaną potrzebą okresowego wycofania się we własną przestrzeń, rozważania w samotności własnych spraw, skupienia na sobie. Potrzebę tę możemy określić jako potrzebę wewnętrznego scalenia ${ }^{35}$. W poszczególnych tomach zwracają uwagę fragmenty pisane niemal kaligraficznym pismem, powiększonymi literami, często w języku francuskim: są to szczególnie ważne dla autorki refleksje dotyczące sensu i celu życia, zwykle treści religijnej; często cytaty z literatury pobożnej.

29 Por. A. Kieniewicz Dziennik, spr. 970, k. 172 b.

30

A. Kieniewicz Dziennik, spr. 982, k. 11.

A. Kieniewicz Dziennik, spr. 977, k. 56 b.

A. Kieniewicz Dziennik, spr. 977, k. 205 b.

A. Kieniewicz Dziennik, spr. 977, k. 152 b.

Wątek chęci bycia czytaną po śmierci pojawia się w czasie I wojny światowej. Por. A. Kieniewicz Dziennik, spr. 983.

Por. A. Girard Le Journal intime et la notion de personne, Firmin Didot, Paris 1963. 
Wycofanie się w siebie pozwala wyodrębnić się ze świata i przeciwstawić mu. Pisanie pozwala wyjść ze stanu rozproszenia i niebytu związanego jak dotkliwie odczuwa autorka - z naturą życia rodzinnego i towarzyskiego, upływającego często na błahych, pozbawionych głębszej wartości rozrywkach. W dziennikach z latami nasila się wątek wanitatywny. Autorka co raz zapewnia siebie, także wśród zabaw i bali, że życie światowe już jej całkowicie zobojętniało. Poczucie niezadowolenia i winy związane z tym stylem życia zwalcza, imając się pożytecznych zajęć w swoim majątku. Mimo że przyjemne i niemal beztroskie - życie doczesne wydaje się jej niedoskonałe i niewystarczające. Jest świadoma nieszczęść spotykających innych i grożących jej samej. Angażuje się coraz bardziej w filantropię we własnej okolicy.

Zagrożona nudą i czczością egzystencji, ale zarazem w pełni akceptująca ideologię konserwatywną, Kieniewiczowa nie marzy o odmianie własnego życia. Choć nieobce są jej dążenia emancypantek do samoistnego określenia własnych celów czy samorealizacji, nie wyraża ich w kategoriach politycznych, ale sięga po nie, decydując o swoim pobożnym stylu życia i narzucając go bezpardonowo mężowi. Raczej nieuświadomione, a jednak rzeczywiste frustracje związane z poczuciem zależności od swego kręgu społecznego i obowiązującego w nim wzorca egzystencji kobiecej, a także niepokój moralny związany z niesprawiedliwością stosunków społecznych, koi wizją bezkonfliktowej i naprawdę szczęśliwej egzystencji w Niebie. Tym samym jej typ religijności wypada uznać za - przede wszystkim - kompensacyjny.

\section{Święta Lela na Polesiu}

"Rozwój duchowy” bohaterki w dzienniku znaczą ślady silnego odzewu na kolejne rozmowy z prałatem Załuskowskim, jego coroczne rekolekcje w Warszawie, a także na takie lektury jak m.in. O naśladowaniu Chrystusa Tomasza à Kempis, Ćwiczenia duchowne Ignacego Loyoli czy Mistyka ks. Piotra Semeneńki. Autorka lubi też rozmawiać o życiu duchowym z wieśniaczką i „,wizjonerką" Romanowską, z zainteresowanymi teozofią panią Dziekońską i krewnymi ${ }^{36}$ czy zainteresowaną teologią nauczycielką z Dereszewicz, Alice Garnier.

W opisach religijności najsilniej zaznacza się wątek wanitatywny i marzenie o Niebie. Autorka skupia się coraz mocniej na „wypełnianiu woli bożej”, którą stara się rozpoznać we własnym życiu. Interesują ją techniki, które mają 
pomóc podporządkować grzeszne ciało duszy i Bogu. W pewnych okresach nasilają się jej praktyki ascetyczne i filantropijne. Przy czym, jak możemy się domyślać ze wzmianek w dzienniku, otoczenie traktuje to jako „dziwactwo”, choć przecież w świetle literatury hagiograficznej okazują się próbą naśladownictwa znanych od wieków wzorów.

Jeśli nie dowierzam zapewnieniom autorki, że jest mistyczką, to dlatego, że wspomniane sąsiedztwo pobożnych westchnień z zapisami jej pragnień i działań wielokrotnie zdradza, nawet przed nią samą, jak wielką rolę w jej dążeniach zawsze odgrywa ambicja bycia lepszą od innych, doskonałą, a także - dostrzeganą i podziwianą. Przez późne dzienniki przewija się marzenie o świętości, autorka wręcz snuje fantazje o kulcie świętej Leli na Polesiu³7. Z notatek wynika przy tym wprost, że dążenie do świętości pojawia się „zamiast": macierzyństwa, ale i autorstwa. Ma związek z coraz silniejszym przekonaniem o braku talentu z jednej strony, i powołania do pisania z drugiej. Pisze np.: „Byłabym lichą autorką, artystką, mogę się stać wielką świętą.”.

Wśród powodzi pobożnych westchnień i zapewnień o oderwaniu od świata tym silniej wybrzmiewają krótkie zdania świadczące o wybuchach zazdrości czy gniewu, wręcz agresji wobec męża czy służącej. Najwyraźniej stosowane techniki nie pomagają Kieniewiczowej pozbyć się negatywnych uczuć, choć z czasem będzie coraz częściej wyrażała skruchę z ich powodu.

Autorka przez lata uprawia kult Matki Boskiej Bolesnej (od 1907 roku każdy tom dziennika otwiera obrazek z jej wizerunkiem), związany z pragnieniem macierzyństwa. Powierza jej duchowe cierpienia, prosi o łaskę zajścia w ciążę. Ale w 1914 roku notuje, że zaniedbała nabożeństwo do niej, bo "gniewa się trochę na nią za to, że nie wysłuchała [jej] prośby" ${ }^{39}$. Także fizyczny, związany z kobiecością, ból nabiera wartości w perspektywie religijnej, tak że autorka wręcz dąży do jego intensyfikacji. Wiosną 1909 roku decyduje się na operację łyżeczkowania macicy, mając nadzieję, że umożliwi to zajście w ciążę. Jej fantazje w tym czasie wyrażają utożsamienie się z katolickimi męczennikami.

Konflikt dążenia do afirmacji i negacji „ja”, dość silnie zaznaczonego indywidualizmu i konserwatywnej wizji powołania kobiety, znajduje u Kieniewiczowej tragiczny wyraz w stosunku do własnej twórczości. Przywodzi

37 Por. A. Kieniewicz Dziennik, spr. 977, k. 30 b i 234 b; spr. 971, k. 39.

38 A. Kieniewicz Dziennik, spr. 977, k. 225.

39 A. Kieniewicz Dziennik, spr. 981, k. 188. 
tym na myśl późniejszą diarystkę, rozdzieraną podobnym konfliktem - Annę Iwaszkiewiczową ${ }^{40}$.

\section{Sataniellowska Chimera}

Na pomysł napisania poematu czy dramatu (wahania co do gatunku świadczą tu wyraźnie o związku z poetyką romantyzmu) Sataniello Kieniewiczowa wpadła wczesną wiosną 1900 roku, kiedy chorując na odrę, ale i rozkoszując się samotnością w ulubionym pokoiku w domu teściów, weszła w specyficzny stan ducha: gorączkowych majaczeń, przypływów strachu przed piekłem, ale także błogości i rozmarzenia, przerywanego rozmowami z teściową o nastroju lat panieńskich albo kontemplacją portretów przodków w galerii. Na początku kwietnia notuje, że przyszedł jej pomysł na nowy dramat, który pełen będzie tworów fantazji i opisów natury ${ }^{41}$. Kilka kart dalej zapisuje zdanie świadczące, że nowy utwór ma mieć charakter autobiograficzny, bo będzie zawierać „fakta ujęte w poetyczną formę" i że w związku z tym zastąpi dotychczasowy dziennik ${ }^{42}$.Z zapisków wynika jednak także, że będzie to „mozaika”, która obejmie „wszystkie narody, wszystkie religie, przeszłość, teraźniejszość i przyszłość, cały plon myśli ludzkiej od niepamiętnych czasów"43. Notuje, że utwór będzie wymagał lat pracy, i zastanawia się, czy, jak Dante, nie umrze w roku jego ukończenia, ale i od razu wątpi, czy w ogóle zrealizuje tak ambitną wizję.

Nie bez znaczenia wydaje się fakt, że dni, w których ją snuje, należą do wyjątkowo szczęśliwych: autorka po wyjściu z choroby upaja się poleską wiosną i erotyzmem, określając pożycie z mężem w tym czasie jako „miodowe miesiące" ${ }^{\prime 4}$.

Z tego i następnych tomów dowiemy się o przygotowaniach do pisania: lekturach geograficznych, historycznych, teologicznych, nawet okultystycznych. Z rozproszonych w czasie uwag możemy wnioskować, że autorka osadziła akcję (lub jej część) w realiach średniowiecznego feudalizmu

40 Por. A. Iwaszkiewicz Dzienniki i wspomnienia, do druku podała M. Iwaszkiewicz, oprac. i przyp.

P. Kądziela, Czytelnik, Warszawa 2012.

Por. A. Kieniewicz Dziennik, spr. 957, k. 110.

A. Kieniewicz Dziennik, spr. 957, k. 124.

A. Kieniewicz Dziennik, spr. 957, k. 124 b.

A. Kieniewicz Dziennik, spr. 957, k. 123. 
i pobożności, i że fragmenty dramatu rzeczywiście powstały ${ }^{45}$. Poza tym co jakiś czas odnotowuje na przemian - gotowość powrotu do niego lub porzucenia na zawsze „Sataniellowskiej Chimery"46. Od rekolekcji 1909 roku aspiracje pisarskie negocjuje bowiem z religijną wizją powołania kobiety, zastanawiając się, czy w ogóle i ewentualnie o czym wypada jej czytać i pisać.

Jeśli w maju 1908 roku pisała, że tworzenie dramatu ją „elektryzuje” i że, tylko pracując nad nim, jest „w swoim żywiole”47, to wkrótce po wielkanocnej spowiedzi u Załuskowskiego w roku 1909 zarejestruje rozpacz, apatię, wstręt do życia. Przestrzega jednak zakazu czytania dzieł okultystycznych i obiecuje sobie, że „pogrzebie [Sataniella] w [jej] kuferku wraz ze wszystkimi brulionami"48. Jest świadoma, że to dla niej „szalone umartwienie"49, ale liczy w zamian na „szczególne łaski od Chrystusa" ${ }^{50}$. Mimo to w 1914 roku napisze: „Całe moje życie jest jednem dążeniem do napisania Sataniella"51, nazwie go też „duchowym synem”52. Powróci do pracy nad nim w czasie wojny, choć co symptomatyczne w wypadku diarystów - wciąż będą to głównie prace przygotowawcze, notatki z lektur ${ }^{53}$.

Sataniello wydaje się wyrażać potrzebę negocjacji między świeckim a hagiograficznym wzorcem egzystencji - rozbudzoną wyobraźnią i zmysłowością autorki, a jedynie dopuszczalnym - w jej przekonaniu - moralnym celem literatury. Z rozproszonych wzmianek o treści dzieła wiemy, że miało w ekspresywny sposób opisywać dzieje wyjątkowego grzesznika, zbrodniarza, który potem w równie spektakularny sposób nawraca się i zostaje świętym. „Sataniello jest to nadczłowiek, przedstawia on cały wiek poprzedzający

Por. A. Kieniewicz Dziennik, spr. 970, k. 69.

Por. A. Kieniewicz Dziennik, spr. 977, k. 36 b.

A. Kieniewicz Dziennik, spr. 966, k. 100 b.

A. Kieniewicz Dziennik, spr. 967, k. 144 b.

A. Kieniewicz Dziennik, spr. 967 k. 143.

Por. A. Kieniewicz Dziennik, spr. 967, k. 144 b.

A. Kieniewicz Dziennik, spr. 982, k. 7 b.

A. Kieniewicz Dziennik, spr. 982, k. 135.

Por. A. Kieniewicz Dziennik, spr. 983. Tezę, że dziennik przeszkadza diarystom pisać dzieło i wręcz często powstaje zamiast niego, postawiła B. Didier. Pewne partie utworu jednak na pewno powstały, choć wzmianka o "kilku tomach" niedokończonego dzieła we wspomnieniach Antoniego Kieniewicza może być przesadzona. Od niego jednak wiemy, że Sataniello był pisany w języku francuskim. Por. A. Kieniewicz Dawno temu, nad Prypeciq̨..., s. 339. 
koniec świata [...] On prowadzi dusze ludzkie do zbawienia"54 - wyjaśnia autorka. Forma nawiązywała prawdopodobnie do wybranych dzieł Słowackiego, Krasińskiego i Flauberta ${ }^{55}$. Plany opisania grzesznego życia Sataniella wydają się tu zapowiadać potrzebę dania upustu wyobraźni i zmysłowości, ale wpisanie fabuły w schemat hagiograficzny staje się gwarancją usprawiedliwienia autorki z sięgnięcia po pióro - w celu wyższym. Wyraźna wydaje się także inspiracja nurtem dekadentyzmu łączącego opisy wyrafinowanego zepsucia z potrzebą metafizyczną, którą koi nawrócenie na katolicyzm ${ }^{56}$. Potwierdzają ją opinie pierwszych słuchaczy utworu: pani Dziekońska zganiła autorkę za "chorobliwe, makabryczne postaci" i „brak miary w dziwacznych opisach" a Klotylda z Kieniewiczów Potworowska dostrzegła, że w utworze jest „dużo modernizmu, a zarazem dużo cech średniowiecznych"58.

Kieniewiczowa nie kryła, że utożsamiała się ze swoim bohaterem ${ }^{59}$, a w roku 1914 całej stronie z dziennika, opisującej jej filantropijne poczynania w Bryniowie, nadaje z satysfakcją tytuł „W życie włożyłam mój dramat Sataniello"60. Znaczące wydaje się i w dziele, i w jej ówczesnej działalności nawiązanie do millenaryzmu. Dziwaczne formy, jakie przyjmuje, można potraktować jako „afekt” - inną niż dyskursywna odpowiedź na nadchodzącą wojnę i rewolucję.

\section{Przypominam dekadenckie postacie}

Adela Kieniewicz nie próbowała odrzucić dominujących w jej epoce wzorców i budowała autonarrację na podstawie katolickiego rozumienia kobiecej tożsamości, mimo to dzięki religii raczej wzmacniała niż negowała własne „ja”. Wypracowała wizję relacji z Bogiem, która podnosiła jej poczucie wartości, zachwiane z jednej strony niemożnością wypełnienia roli matki dziedzica,

54 A. Kieniewicz Dziennik, spr. 957, k. 124 b.

W tym Króla-Ducha, Beniowskiego, Agaj-hana. Irydiona, Salambo i Kuszenia świętego Antoniego - świadczy o tym bliskość uwag o ich lekturze i zapisków dotyczących własnego dramatu. Por. np. A. Kieniewicz Dziennik, spr. 970, k. 123 b.

Czyli np. Boudelaire'a i Hyusmansa.

Por. A. Kieniewicz Dziennik, spr. 968, 37b.

Por. A. Kieniewicz Dziennik, spr. 970, k. 134 b.

60 A. Kieniewicz Dziennik, spr. 982, k. 173. 
z drugiej poczuciem, że brak jej talentu, który gwarantowałby sukces w świecie. Przy okazji, być może, zanurzenie w pobożnych rozmyślaniach pomagało jej wytłumić niezgodne z obowiązującym wzorcem kobiecej egzystencji impulsy twórcze, które wciąż znajdowały pewne ujście w formie „pisania dla siebie", czyli dzienniku. Jego autorka uznawała swoją pozycję za wpisaną w porządek społeczny chciany przez Boga i starała się z nią pogodzić mimo silnego dyskomfortu psychicznego. Zarazem, odrzucając prawa świata na rzecz wyższego porządku moralnego, utwierdzała się w poczuciu wyższości duchowej nad otoczeniem, zyskując tym samym we własnym poczuciu siłę i autonomię.

Nie sztuka, ale wybujała pobożność, oglądająca się na décadence, stała się medium jej indywidualizmu, bo autorka wiedziała, że otoczenie nie może jej wprost zakwestionować.

\section{Abstract}

\section{Katarzyna Nadana-Sokołowska}

THE INSTITUTE OF LITERARY RESEARCH OF THE POLISH ACADEMY OF SCIENCES (WARSAW) The Diary of Adela Kieniewicz: A Woman Writing at the Turn of the Twentieth Century

Nadana-Sokołowska presents preliminary findings of a study of the vast collection of diaries that came to light when members of the research project "Pamiętniki i listy polskich autorów z Ziem Zabranych" [Diaries and Letters of Polish Writers from the Lands Annexed by the Russian Empire], directed by Wiesław Caban searched the Central Historical Archives in Kiev. Nadana-Sokołowska discusses the significance of these documents for research on women's autobiographies in Poland in the context of autobiography studies (e.g. Girard, Didier, Lejeune). Reading these diaries alongside the journals of Zofia Nałkowska and Anna Iwaszkiewicz, Nadana-Sokołowska explores the religiosity of life writing and the resulting inner conflict concerning the diary writer's literary creativity.

\section{Keywords}

Adela Kieniewicz, life writing, modernism, religiosity, decadence 